\title{
Should the Bidirectional Glenn Operation be performed with or without cardiopulmonary bypass?
}

A operação de Glenn bidirecional deve ser realizada com ou sem o auxílio de circulação extracorpórea?

Ulisses Alexandre CROTI, Domingo Marcolino BRAILE, Moacir Fernandes de GODOY, Harold Gonzalez MURILlO, Carlos Henrique De MARCHI, Miriam Yukiko CHIGUTTI, Omar Yesid Prieto RINCON, Airton Camacho MOSCARDINI

RBCCV 44205-694

\section{Abstract}

Objective: To compare patients who underwent the Bidirectional Glenn Operation with and without cardiopulmonary bypass (CPB), analyzing the characteristics and confirming if there is superiority of either of the employed techniques.

Method: Between January 2002 and January 2004, 16 patients with complex heart defects were submitted to this operative technique. The mean age of the patients was 19 months and 14 were female. The patients were divided into two groups: Group A with 7 patients (using CPB) and group B with 9 patients (without the use of $C P B)$. Gender, age, mean pulmonary artery pressure (MPAP), CPB time, aortic clamping time, venoatrial shunt, previous operations, time in intensive care unit (ICU), total hospitalization time and immediate complications were all compared between the two groups.

Results: The median MPAP was $13 \mathrm{mmHg}$. In group A the CPB time was $91 \pm 47$ minutes (57-195 minutes), myocardial ischemia was $25 \pm 33$ minutes (0-80 minutes). Of these, four patients required intracardiac procedures or enlargement of the pulmonary branches and in three, CPB assistance as ventilatory support was needed. In group $B$ the venoatrial shunt was $21 \pm 10$ minutes $(0-39$ minutes $)$. The time to extubation was $9 \pm 13$ hours with a median of 3 hours (1-43 hours). The ICU stay was $8 \pm 12$ days with a median of 5 days (1-50 days). Hospitalization was $12 \pm 12$ days with a median of 7 days (0-50 days). Five patients had been submitted to surgeries previously. Two, one patient from each group, died $(\mathbf{1 2 . 5 \% )}$. No neurological complications, pleural or pericardial effusions were observed. No significant differences were evidenced between the two groups in respect to all the variables studied.

Conclusion: In spite of the relatively small cohort, this study suggests that the bidirectional Glenn operation can be performed with or without CPB giving similar results in respect to morbidity and mortality. Thus, the operation without CPB can be safely employed when the anatomic findings are appropriate and there is no severe hypoxia.

Descriptors: Heart defects, congenital, surgery. Pulmonary artery, surgery. Vena cava, superior, surgery. Extracorporeal circulation.

Work performed in Hospital de Base Medicine School, São José do Rio Preto, Brazil.

Correspondence address: Av. Brigadeiro Faria Lima, 5416 - Sala $07-$ São José do Rio Preto - SP - CEP: 15090-000 Brazil - Telephone (Fax): 17-210 5025. E-mail: uacroti@uol.com.br 


\section{Resumo}

Objetivo: Comparar os pacientes onde a operação foi realizada com circulação extracorpórea (CEC) àqueles sem CEC, analisando suas características e verificando se houve ou não superioridade de alguma das técnicas empregadas.

Método: Entre janeiro de 2002 e janeiro de 2004, 16 pacientes foram submetidos à operação de Glenn bidirecional (GB), todos com defeitos cardíacos complexos. Quatorze eram do sexo feminino, com idade mediana de 19 meses. Os pacientes foram divididos em dois grupos: $A$ (GB com CEC) e B (GB sem CEC), sendo sete do grupo A e nove do grupo $B$. Foram analisadas comparativamente as variáveis: sexo, idade, pressão arterial pulmonar média (PAPM), operação realizada, tempo de CEC, pinçamento da aorta, derivação venoatrial, operações prévias, internação na unidade de terapia intensiva (UTI), hospitalização e complicações imediatas.

Resultados: A mediana da PAPM foi 13 mmHg. No grupo A, o tempo foi de CEC $91 \pm 47$ minutos (57-195 minutos) e o de isquemia miocárdica $25 \pm 33$ minutos (0-80 minutos). Destes, quatro necessitaram de procedimento intracardíaco ou ampliação de ramos pulmonares e três, auxílio da CEC como

\section{INTRODUCTION}

The bidirectional Glenn (BG) or bidirectional superior cavopulmonary (BSCP) operations consist of end-to-side anastomosis between the superior vena cava and the right pulmonary artery. When the left superior vena cava is also anastomosed to the left pulmonary artery the operation is denominated bicaval BG [1]. It is a well-established palliative surgical procedure for the treatment of several congenital heart diseases with a univentricular physiology and can be performed at an earlier stage or concomitantly with the Fontan-type operations [2]

Since the BUCP anastomosis was shown to be superior [3] when compared to the original procedure proposed by GLENN [4], the operation started to be used generally together with cardiopulmonary bypass (CPB). In 1990, LAMBERTI et al. [5] reported the possibility of preparing the anastomosis utilizing a temporary venoatrial shunt without $\mathrm{CPB}$.

Several patients have been submitted to the BG without the use of CPB with the aim of avoiding its complications [57]. Thus, we aimed at comparing patients submitted to operations both on-pump and off-pump, analyzing their characteristics and verifying if one of the techniques was superior.

\section{METHOD}

In the period from Janeiro 2002 to Janeiro 2004, 16 patients were submitted to the BG operation by median transsternal thoracotomy. All the patients were operated on in the suporte ventilatório. No grupo $B$ o tempo de desvio venoatrial foi de $21 \pm 10$ minutos (0-39 minutos). $O$ tempo para extubação $9 \pm 13$ horas, mediana 3 horas (1-43 horas). A permanência UTI foi de $8 \pm 12$ dias, mediana 5 dias (1-50 dias). $O$ período médio de internação hospitalar foi de $12 \pm 12$ dias, mediana 7 dias (0-50 dias). Cinco pacientes haviam sido submetidos à operação prévia. Dois $(12,5 \%)$ faleceram, sendo um em cada grupo. Não houve complicações neurológicas, derrame pleural ou pericárdico. Todas as variáveis estudadas entre os grupos não apresentaram diferença estatística significativa.

Conclusão: Apesar da amostra relativamente pequena, o presente estudo sugere que a operação de GB pode ser realizada com ou sem CEC com resultados semelhantes no que se refere à morbidade e mortalidade. Assim sendo, a operação sem CEC pode ser empregada com segurança quando os achados anatômicos forem apropriados e não houver hipóxia grave.

Descritores: Cardiopatias congênitas, cirurgia. Artéria pulmonar, cirurgia. Veia cava superior, cirurgia. Circulação extracorpórea.

University Hospital de Base in São José do Rio Preto, Brazil. The research was approved by the Ethics Committee for Research at the institution.

Fourteen $(87.5 \%)$ were women. The mean age was $49 \pm$ 54 months with a median of 19 months. The mean weight was $15 \pm 11 \mathrm{~kg}$ with a median of $8 \mathrm{~kg}$. The diagnoses are shown in Table 1.

All patients with univentricular physiology were included in the study independent of previous surgeries or associated procedures. Cineangiocardiographic studies were performed in 14 patients to check the mean pulmonary artery pressure (MPAP) and in two patients it was measured during the surgical procedure.

Additional to the MPAP, the following variables were comparatively analyzed: gender, age, operation performed, CPB time, venoatrial shunt time, time of aortic clamping, previous surgeries, time of ICU stay, time of hospitalization and complications in the immediate postoperative period.

The patients were allocated to two groups. In one group cannulae were introduced to the aorta, brachiocephalic vein and the inferior vena cava, with the temperature controlled dependent on the necessary associated procedures. This technique was utilized every time that an intracardiac repair was required, for enlarging of the pulmonary branches or as ventilatory support for severe hypoxia. When the operation did not utilize CPB, a shunt was installed in the brachiocephalic vein to the right atrium using a normal venous cannula (Figure 1). The ligature of the hemiazygos vein was systematically performed in all operations.

In the statistical analysis, the nominal variables were compared using the Fisher Exact test. The quantitative 
variables with Gaussian distributions were compared using the non-paired student t-test, while the quantitative variables without Gaussian distribution or with a large standard deviation were compared using the Mann-Whitney test. Two-tailed comparisons were employed. P-values = 0.05 were considered significant.

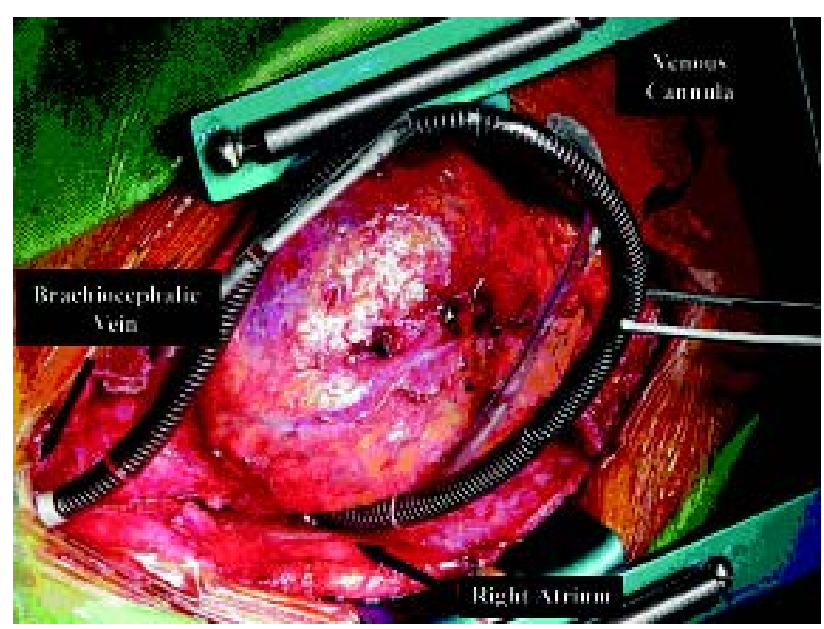

Fig. 1 - Intraoperative aspect of the venoatrial shunt from the brachiocephalic vein to the right atrium, which is utilized to prepare the bidirectional Glenn operation without the use cardiopulmonary bypass. Also adherences related to a previous modified BlalockTaussig operation can be observed.

\section{RESULTS}

The mean age of the total group at the moment of the operation was $49 \pm 54$ months with a median of 19 months (range 5 to 170 months). In Group A the mean age was $66 \pm$ 57 months with a median of 70 months ( 8 to 170 months). In group B the mean age was $37 \pm 50$ months with a median of 17 months (5 to 125 months). Analysis using the MannWhitney test comparing the two groups demonstrated a pvalue $=0.1738$.

The diagnoses, operations and times of $\mathrm{CPB}$, venoatrial shunts and myocardial ischemia are shown in Table 1.

The preoperative MPAP was $15 \pm 5 \mathrm{mmHg}$ with a median of $13 \mathrm{mmHg}$. In the Groups A and B the medians were similar to the total group. When the student t-test was applied between the groups, the p-value was 0.9293 .

In Group A, the mean time of CPB was $91 \pm 47$ minutes with a median of 77 minutes $(57-195$ minutes). The mean myocardial ischemia time was $25 \pm 33$ minutes with a median of eight minutes ( $0-80$ minutes). In Group B the mean venoatrial shunt time was $21 \pm 10$ minutes with a median of 21 minutes. In this group there was no myocardial ischemia.

Of the seven patients of Group A, four $(57.1 \%)$ required intracardiac procedures or enlargement of the pulmonary branches. In three (42.9\%) there was no myocardial ischemia, and $\mathrm{CPB}$ was used only as ventilatory support due to severe hypoxia. Of the nine patients (100\%) of Group B who did not require other procedures, the venoatrial shunt was sufficient to maintain adequate oxygenation during the operation. There was no correlation between deaths and operations with or without CPB, (p-value $=1$ - Fisher exact test). Three patients (18.8\%) underwent bicaval BG, two from Group A and one from Group B.

Of all the 16 patients in the study, five (31.1\%) had been submitted to operations previously. Three patients (42.9\%) of Group A had been operated on, two for the modified Blalock-Taussig operation and one a pulmonary branch banding. In Group B, 2 patients (22.2\%) had been submitted to the modified Blalock-Taussig operation previously. On analysis using the Fisher exact test, the correlation between deaths and previous operations gave a $\mathrm{p}$-value $=1$.

The mean time to extubation was $9 \pm 13$ hours, with a variation of 1 to 43 hours and a median of 3 hours for the total group. In Group A the time was $8 \pm 11$ hours with a variation of 2 to 33 hours and a median of 3 hours. In Group $\mathrm{B}$ the time to extubation was $11 \pm 15$ hours ranging from 1 to 43 hours and a median of 3 hours. It is important to stress that a patient who stayed for 50 days in the ICU was extubated after 12 postoperative hours however during the evolution it was necessary to reintubate several times. The Mann-Whitney test demonstrated that the time of extubation was not dependent on the technique employed, that is with or without $\mathrm{CPB}(\mathrm{p}$-value $=0.8371)$.

The mean time of stay in the ICU was $8 \pm 12$ days with a variation of 1 to 50 days for the total group. In Group A the stay was $5 \pm 4$ days with a variation of 1 to 12 days and a median of 3 days. In Group B the stay was $10 \pm 15$ days with a variation of 3 to 50 days and a median of 5 days. Excluding the patient who stayed for 50 days in the ICU and eventually died, the mean time of ICU stay was $5 \pm 2$ days with a median of 5 days. Using the Mann-Whitney test a p-value of 0.2991 was obtained confirming the length of stay in the ICU did not depend on the technique.

Four patients $(25 \%)$ presented with infection of the respiratory tract in the postoperative period. Two were from group A and two from Group B. One patient of Group B was reoperated on the second postoperative day for bleeding owing to an injury of the aorta after pulmonary physiotherapy.

The mean hospital stay was of $12 \pm 12$ days with a variation of 0 to 50 days and a median of 7 days for the total group. In group A the mean hospital stay was $9 \pm 7$ days with a variation of 0 to 21 days and a median of 6 days. Excluding the patient who died 12 hours after the procedure, the mean hospital stay was $10 \pm 6$ days with a median of 7 days. In Group B the mean hospital stay was $15 \pm 14$ days with a variation of 5 to 50 days and a median of 11 days. Excluding the patient who died after 50 days in the ICU, the 


\begin{tabular}{|c|c|c|c|c|}
\hline PATIENT & DIAGNOSIS & OPERATION & $\mathrm{TP} / \mathrm{DV}$ & TIM \\
\hline \multicolumn{5}{|c|}{ With CPB (Group A) } \\
\hline $1 *$ & $\begin{array}{l}\text { unbalanced PAVSD, tricuspid valve stenosis, slight } \\
\text { valvar pulmonary stenosis }\end{array}$ & $\begin{array}{l}\mathrm{BG} \text {, burying of the right ventricle } \\
\text { with tricuspid valve closure, IAC } \\
\text { enlargement, ligature of the } \\
\text { pulmonary branch }\end{array}$ & 84 & 60 \\
\hline 2 & $\begin{array}{l}\text { Right-type UV, pulmonary atresia, PAC, BT of the } \\
\text { aorta to right pulmonary artery occluded }\end{array}$ & $\begin{array}{l}\text { BG, enlargement of the pulmonary } \\
\text { artery, ligature and sectioning of the } \\
\text { arterial canal, sectioning of the } \\
\text { pulmonary branch, resection of the BT }\end{array}$ & 195 & 80 \\
\hline 3 & $\begin{array}{l}\text { Complex univentricular heart disease with left atrial } \\
\text { isomerism, single atrium, DRVOFT, subaortic IVS, } \\
\text { single atrioventricular valve with moderate } \\
\text { insufficiency, slight ventricular dysfunction, agenesis } \\
\text { of the superior vena cava to the right, inferior vena } \\
\text { cava and supra-hepatic veins draining to the right } \\
\text { atrium, inferior territory draining by the azygos in } \\
\text { the patent left superior vena cava }\end{array}$ & $\begin{array}{l}\text { BG, maintaining the supra-hepatic } \\
\text { veins in the right atrium }\end{array}$ & 77 & - \\
\hline 4 & TA IC, restrictive IVS, LSVCP & BG bicaval & 57 & - \\
\hline 5 & $\begin{array}{l}\text { Pulmonary atresia with integral septum, BT to the } \\
\text { right }\end{array}$ & $\begin{array}{l}\mathrm{BG} \text {, resection of the } \mathrm{BT} \text {, enlargement } \\
\text { of the right pulmonary artery with the } \\
\text { superior vena cava, atrioseptectomy }\end{array}$ & 65 & 8 \\
\hline 6 & Ebstein Disease, IAS, IVS & $\begin{array}{l}\mathrm{BG} \text {, atrioseptectomy, ligature } \\
\text { pulmonary branch }\end{array}$ & $\begin{array}{l}8 \\
6\end{array}$ & 30 \\
\hline 7 & TA IC, banding of the pulmonary branch, IVS, LSVCP & BG bicaval & 70 & - \\
\hline \multicolumn{5}{|c|}{ Without CPB (GROUP B) } \\
\hline 8 & Left-type SV, IVPS & $\mathrm{BG}$, ligature pulmonary branch & 21 & - \\
\hline 9 & $\begin{array}{l}\text { TMA, predominant right ventricle, subvalvar } \\
\text { pulmonary stenosis }\end{array}$ & $\mathrm{BG}$, ligature pulmonary branch & 39 & - \\
\hline 10 & Right-type SV, DRVOT, IVPS, BT left & $\begin{array}{l}\mathrm{BG} \text {, ligature pulmonary branch, } \\
\text { ligature and sectioning of the } \mathrm{BT}\end{array}$ & 20 & - \\
\hline 11 & TAVSD unbalanced, DRVOT, IVPS & BG & 21 & - \\
\hline 12 & Left-type SV, pulmonary atresia & BG & 19 & - \\
\hline 13 & TA IB, restrictive IVS & BG, pulmonary branch banding & 27 & - \\
\hline $14 *$ & $\begin{array}{l}\text { Left-type SV, rudimentary right ventricle, DRVOT, } \\
\text { significant IVS, BT to the left }\end{array}$ & $\begin{array}{l}\mathrm{BG} \text {, ligature pulmonary branch, } \\
\text { ligature and sectioning of the } \mathrm{BT}\end{array}$ & 26 & - \\
\hline 15 & TA IB & BG, pulmonary branch banding & 17 & - \\
\hline 16 & $\begin{array}{l}\text { Right-type SV, hyperplastic left ventricle, DRVOT, } \\
\text { IVPS, LSVCP }\end{array}$ & $\begin{array}{l}\text { BG, bicaval pulmonary branch } \\
\text { banding }\end{array}$ & - & - \\
\hline
\end{tabular}

CPB: cardiopulmonary bypass, PT: perfusion time (minutes), VS: venoatrial shunt time (minutes), MIT: myocardial ischemia time (minutes), -: without venoatrial shunt or myocardial ischemia, PAVSD: partial atrioventricular septum defect, BG: bidirectional Glenn, IAS: interatrial shunt, SV: single ventricle, PAC: patent arterial canal, BT: modified Blalock-Taussig, DRVOT: Double right ventricle outflow tract, IVS interventricular shunt, TA: tricuspid atresia, TMA: transposition of the major arteries, IVPS: infundibulum-valvar pulmonary stenosis, TAVSD: total atrioventricular septum defect, LSVCP: left superior vena cava patent, *: deaths. 
mean hospital stay was $11 \pm 6$ days with a median of 8 days. Applying the Mann-Whitney test, there were no significant differences between the two techniques utilized ( $\mathrm{p}$-value $=$ 0.4079).

There were no neurological complications or pleural or pericardial effusions during the study period.

Two patients died (12.5\%), one from Group A (14.3\%) and one from Group B (11.1\%). The patient from Group A had been extubated after three postoperative hours and presented with cardiac arrest after 12 hours. The patient from Group B died on the $50^{\text {th }}$ postoperative day from sepsis.

\section{COMMENTS}

The Glenn operation as it was originally described was performed by thoracotomy and without CPB [4], however the distribution of venous blood flow was not bidirectional. With the evolution, it is easy to see the great advantages of the BG operation in reducing the ventricular volume overload and in the better peripheral systemic saturation, with a consequent improvement in the functional degree [8].

Several publications demonstrated that $\mathrm{BG}$ can be successfully performed in under 6-month-old children $[7,8]$, thus frequently this avoids prior BT or pulmonary branch banding operations. In the studied group the median was 19 months, which demonstrates the delay from diagnosis to surgical treatment of these patients. When the ages between the two groups were compared, this variable was not considered an important factor in respect to performing the BG surgery with or without CPB. Some patients presented with ages for the Fontan operation, however the adopted strategy is to perform BG followed by the Fontan-type operation as a second stage.

One of the first parameters to be evaluated when considering performing BG is the MPAP, for which cineangiocardiography is necessary. When this is not possible due to the emergency nature of the surgery, the MPAP can be measured in the intraoperative period, as was done with two patients in our study. A MPAP of more than $17 \mathrm{mmHg}$ or for under 4-month-old children more than 21 $\mathrm{mmHg}[8]$ is considered a higher risk [9] as the presence of an anterograde pulmonary flow can cause higher pressures. In our series the median pressure was $13 \mathrm{mmHg}$, an adequate level which was not considered to be associated to risk of mortality. These data reflect the rigid criteria followed before indicating BG.

Generally the presence of associated anomalies requires intracardiac repairs or enlargement of the pulmonary branches. In this situation CPB is imperious, despite of the well-known complications such as myocardial and pulmonary edema, and a temporary increase in the pulmonary diastolic pressure or pulmonary vascular resistance. To neutralize the effects of $\mathrm{CPB}$ we utilized the modified ultrafiltration technique, which helps to reduce the prevalence of pleural effusions and reduces hospitalization stay [10]. This may be the reason that we did not evidence significant differences between the two groups in respect to neurological complications, pleural and pericardial effusions and extubation times.

The bicaval BG surgery is performed when there are two patent superior cavas from the left superior vena cava. The three patients operated on with this anatomy did not present with complications or die. However, special attention should be paid to these patients when heterotaxy is associated, which is recognized as a risk factor for mortality [11]. In one of the patients from Group B the operation was performed without the venoatrial shunt and without neurological complications, a technique which has been routinely used by us, as well as by other teams [6,7] for patients with double superior cava systems.

The mean time of the venoatrial shunt in the off-pump group was 21 minutes, a little longer than reported in the literature [6]. Although we did not measure the venous pressure at the moment of clamping to prepare for the BG, it is important to stress that there were no neurological complications. The late follow-up may give further information in respect to the cognitive development of these patients. Some authors recommend that the venoatrial shunt is not necessary to prepare the BG when the central venous pressure is low and the time of clamping of the superior vena cava is less than 15 minutes [6].

The patients who underwent previous operations with BT or pulmonary artery branch banding may present with stenosis of the pulmonary branches, making the use of CPB inevitable for the correction of defects [5]. This did not occur in all our patients, even though two of them had previously been submitted to the BT surgery and the BG operation was performed without $\mathrm{CPB}$ demonstrating that enlargement of the pulmonary branches is not always required.

The postoperative management was similar for both groups, with a reduction of the pulmonary vascular resistance to facilitate venous return. The hematocrit level was maintained between 40 and $45 \%$. Thus, there were no significant statistical differences in the time of ICU stay and the total time of hospitalization.

One patient from Group A probably died due to arrhythmia or pulmonary embolia. The operation included burying the tricuspid valve using a bovine pericardium patch, that is, utilization of CPB together with great quantity of intracardiac exogenous material.

The patient from Group B died on the $50^{\text {th }}$ postoperative day owing to sepsis. Culture tests were positive for pseudomonas aeruginosa, klebsiela pneumoniae and candida albicans. This patient remained in the ICU during 
all the time of hospitalization, was extubated on several occasions and did not present with an adequate respiratory pattern or peripheral oxygen saturation. It is important to remember that the previous MPAP was $28 \mathrm{mmHg}$ with anterograde flow, which is associated to greater mortality [12]. A very tight band was used on the pulmonary branch, leaving a small anterograde flow associated with the BG in such a way that the postoperative MPAP was less than 14 $\mathrm{mmHg}$. This surgical strategy, however, did not benefit the patient who evolved to death by respiratory insufficiency and uncontrolled pulmonary infection.

\section{CONCLUSION}

In spite of the relatively small sample size, this study suggests that the BG operation can be performed with or without the use of CPB giving similar results in respect to the morbidity and mortality rates. Thus, the off-pump operation can be safely employed when intracardiac repairs and enlargement of the pulmonary branches are not necessary or when there is no severe hypoxia.

\section{BIBLIOGRAPHIC REFERENCES}

1. Croti UA, Braile DM, Maisano ACLFB, Selig FA. Correlação clínico-cirúrgica. Rev Bras Cir Cardiovasc 2004;19:188-9.

2. Duncan BW, Desai S. Pulmonary arteriovenous malformations after cavopulmonary anastomosis. Ann Thorac Surg 2003;76:1759-66

3. Hopkins RA, Armstrong BE, Serwer GA, Peterson RJ, Oldham HN. Physiological rationale for a bidirectional cavopulmonary shunt: a versatile complement to the Fontan principle. J Thorac Cardiovasc Surg 1985;90:391-8.
4. Glenn WW. Circulatory bypass of the right side of the heart: shunt between superior vena cava and distal right pulmonary artery. Report of clinical application. N Engl J Med 1958; 259:117-20

5. Lamberti JJ, Spicer RL, Waldman JD, Grehl TM, Thomson D, George L et al. The bidirectional cavopulmonar shunt. J Thorac Cardiovase Surg 1990;100:22-30.

6. Jahangiri M, Keogh B, Shinebourne EA, Lincoln C. Should the bidirectional Glenn procedure be performed through a thoracotomy without cardiopulmonary bypass? J Thorac Cardiovasc Surg 1999;118:367-8.

7. Liu J, Lu Y, Chen H, Shi Z, Su Z, Ding W. Bidirectional Glenn procedure without cardiopulmonary bypass. Ann Thorac Surg 2004;77:1349-52.

8. Reddy MV, Liddicoat JR, Hanley FL. Primary bidirectional superior cavopulmonary shunt in infants between 1 and 4 months of age. Ann Thorac Surg 1995;59:1120-6.

9. Pridjian AK, Mendelsohn AM, Lupinetti FM, Beekman RH, Dick M, Serwer G et al. Usefulness of the bidirectional Glenn procedure as staged reconstruction for the functional single ventricle. Am J Cardiol 1993;71:959-62.

10. Koutlas TC, Gaynor JW, Nicolson SC, Steven JM, Wemovsky G, Spray TL. Modified ultrafiltration reduces postoperative morbidity after cavopulmonary connection. Ann Thorac Surg 1997;64:37-43.

11. Mainwaring RD, Lamberti JJ, Uzark K, Spicer RL. Bidirectional Glenn: is accessory pulmonary blood flow good or bad? Circulation 1995; 92 (9 Suppl II):II294-7.

12. Pineda LF, Cazzaniga M, Villagrá F, Balda JID, Daghero F, Sarachaga IH et al. La operación de Glenn bidireccional em 100 casos con cardiopatías congénitas complejas: factores determinantes del resultado quirúrgico. Rev Esp Cardiol 2001;54:1061-74. 